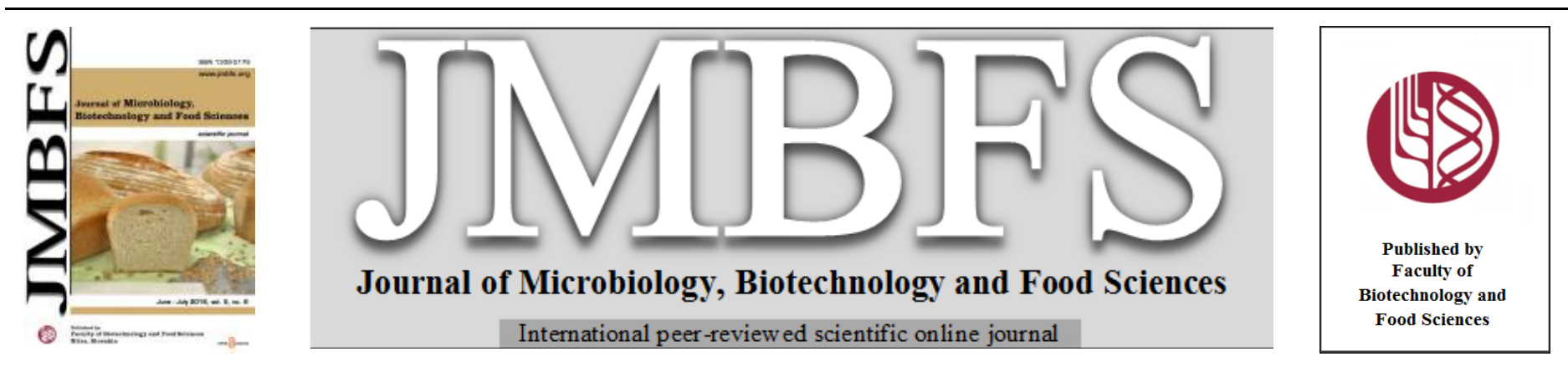

\title{
PURIFICATION AND CHARACTERIZATION OF SOLVENT STABLE LIPASE FROM A SOLVENT TOLERANT STRAIN OF GEOBACILLUS STEAROTHERMOPHILUS PS 11
}

\author{
Payel Sarkar ${ }^{1}$, Khusboo Lepcha ${ }^{2}$,Shilpi Ghosh ${ }^{1}$ \\ Address(es): Dr. Shilpi Ghosh, \\ ${ }^{I}$ Department of Biotechnology, University of North Bengal, Siliguri 734013, India. \\ ${ }^{2}$ Department of Microbiology, University of North Bengal, Siliguri 734013, India.
}

*Corresponding author: ghosshilpi@gmail.com

doi: 10.15414/jmbfs.2016.5.6.602-605

\section{ARTICLE INFO}

Received 4. 3. 2014

Revised 26. 2. 2016

Accepted 1.3. 2016

Published 1. 6. 2016

Regular article

oPEN $\bigodot_{\text {ACCESS }}$

\section{ABSTRACT}

An extracellular organic solvent stable lipase produced by solvent tolerant strain of Geobacillus stearothermophilus PS11 was purified and characterised. The overall purification was 8.04 fold with a yield of $22.6 \%$. The molecular weight of purified lipase was approximately $27.5 \mathrm{kDa}$. The purified lipase activity was stable $(745 \mathrm{EU} / \mathrm{ml}$ at $72 \mathrm{~h}$ incubation) in presence of toluene, benzene, propanol, methanol etc. The enzyme activity was maximum $(764 \mathrm{EU} / \mathrm{ml})$ when assayed under optimum temperature and $\mathrm{pH}$ of $50^{\circ} \mathrm{C}$ and 10.0 , respectively. The enzyme showed stability at a wide range of temperature from $10^{\circ} \mathrm{C}$ to $60^{\circ} \mathrm{C}$. This solvent stable lipase can be a novel tool for biodiesel industry.

Keywords: Solvent stable, lipases, Geobacillus stearothermophilus

\section{INTRODUCTION}

Diesel fuels are the key to the industrial economy of a developing country. With the industrialization bloom in the whole globe, the world is confronted with the twin crises of fossil fuel depletion and environmental degradation Van. (2005). In order to resolve these problems, researchers are interested to find an alternative environmental friendly reproducible diesel fuel. Biodiesel is an alternative diesel fuel that is produced from vegetable oils or animal fats. It have the following advantages over diesel fuel: produce less smoke and particulates, have higher cetane numbers, produce lower carbon monoxide and hydrocarbon emissions, are biodegradable, and nontoxic engine lubricity to low sulfur diesel fuels. With this huge range of advantages, it is gaining more and more importance as an alternative fuel. Lipase is the key enzyme used to produce biodiesel (Marchetti et al. 2005, Barnwal and Sharma 2005). Only organic solvent tolerant lipase, especially tolerating methanol and ethanol, can distinctly improve the production of biodiesel (Kaieda et al. 2001). Till date, the number of bacteria producing organic solvent tolerant lipase is limited, and most of the isolated organic solvent-tolerant strains belong to the genera are Pseudomonas isolated from soil or marine samples [5]. We have previously isolated a solvent tolerant strain of Bacillus thermophilus PS11 (now known as Geobacillus stearthermophilus) that could grow in presence of wide range of solvents. In this work, we report that the bacterial strain is capable of producing lipase that is stable in presence of various solvents such as toluene, n-octanol, propanol, methanol, benzene etc. This will open novel and simpler routes for the synthetic processes and in turn pave a route to alternative biodiesel production.

\section{MATERIAL AND METHODS}

\section{Isolation of lipase producing solvent tolerant bacterial strains}

Solvent tolerant strain of Geobacillus stearothermophilus PS11 (accession no KC311354), previously isolated from soil is used in this study Sarkar and Ghosh (2012). It was plated on nutrient agar supplemented with $1 \%$ tributyrin. After $48 \mathrm{~h}$ of incubation at $37^{\circ} \mathrm{C}$, the lipolytic activity was confirmed by the formation of a clear zone around the colonies.

\section{Measurement of bacterial growth}

Overnight grown culture of PS11 strain was inoculated in nutrient broth overlaid with $5 \%$ tributyrin and incubated at $37{ }^{\circ} \mathrm{C}$ under shaking condition at $140 \mathrm{rpm}$.
Growth and dry cell mass of the isolate was determined according to the process described by Sarkar and Ghosh (2012).

\section{Production media and enzyme preparation}

A $1 \%(\mathrm{v} / \mathrm{v})$ bacterial suspension was transferred from an overnight nutrient broth seed culture to the basal production medium (LPM-1) composed of $\left(\mathrm{g} \mathrm{l}^{-1}\right)$ peptone 5 , beef extract 3 , sodium chloride 2 , tween 805 and olive oil $10, \mathrm{pH} 8$. Bacterial cells were grown at $37^{\circ} \mathrm{C}$ under shaking condition at $140 \mathrm{rpm}$ for $96 \mathrm{~h}$ After every $24 \mathrm{~h}$ cells were removed by centrifugation and the supernatant was desalted and used for measurement of lipase activity.

\section{Lipase assay and protein content determination}

Lipase activity was measured on the basis of hydrolysis of p-nitro phenyl palmitate (pNPP). A $2.5 \mathrm{ml}$ of the assay mixture consisted of, $2.4 \mathrm{ml}$ of $50 \mathrm{mM}$ Tris $\mathrm{HCl}(\mathrm{pH} 9)$ with $\mathrm{pNPP}$ and $0.1 \mathrm{ml}$ concentrated enzyme preparation. Incubation of the reaction mixture at $60^{\circ} \mathrm{C}$ for 10 minutes was followed by addition of $200 \mu \mathrm{l}$ of $1 \mathrm{M}$ calcium chloride. The precipitation of free fatty acids with calcium chloride was used to detect lipase activity. Release of p-nitrophenol (pNP) from pNPP was measured as the increase in absorption at $410 \mathrm{~nm}$. One lipase unit is defined as the amount of enzyme that liberated $1 \mu \mathrm{M}$ p-nitro phenol per minute under the assay conditions.

\section{Optimization of production media}

Optimization of process parameters and manipulation of media composition are the most important techniques used for the overproduction of lipase to meet industrial demands. Optimization was carried out through modification of several growth parameters. For these, the bacterial cells were grown for $96 \mathrm{~h}$ at $37^{\circ} \mathrm{C}$ under shaking condition. The cells were removed by centrifugation and the supernatants were used for measurement of lipase activity. The various parameters optimized for obtaining maximal lipase yield were, incubation time $(24,48,72$ and $96 \mathrm{~h})$, agitation speed $(100-200 \mathrm{rpm})$. Substrate specificity was determined using $1 \%$ (v/v) rice bran oil, sunflower oil, soybean oil, olive oil, and mustard oil. Further the effect of various carbon sources $(1 \% \mathrm{w} / \mathrm{v})$ such as glucose, sucrose, lactose, maltose, and nitrogen sources $(1 \% \mathrm{w} / \mathrm{v})$, that is, soybean meal, sodium nitrate, peptone, beef extract, yeast extract were also examined for production of lipase. For each step lipase activity was assayed under standard condition to know the optimal yield. 


\section{Purification and Molecular weight of crude enzyme}

The bacterial isolate was cultured in LPM- 1 for $72 \mathrm{~h}$ at $37^{\circ} \mathrm{C}$. Bacterial cells were removed by using cooling centrifuge $\left(4^{\circ} \mathrm{C}\right)$ at $5000 \mathrm{rpm}$ for $10 \mathrm{~min}$. The enzyme was precipitated by adding solid ammonium sulphate $(0-40 \%)$ at $4{ }^{\circ} \mathrm{C}$ for $24 \mathrm{~h}$. The precipitate was collected by centrifugation at $10,000 \mathrm{rpm}$ for $40 \mathrm{~min}$ and dissolved in $50 \mathrm{mM}$ Tris $\mathrm{HCl}$ buffer (pH 9.0). It was then desalted by dialysis with a cellulose dialysis bag (3500 Da pore-size) in same buffer. The desalted enzyme preparation was loaded on to DEAE-sephacel column. The active fractions were collected, lyophilized and applied on sephadex G75 column. The active fractions were used to determine the molecular weight. Protein content (mg $\mathrm{ml}-1$ ) was determined by Lowry method Lowry et al. (1951).

Molecular weight of lipase was detected on $15 \%$ polyacrylamide slab gel using mini gel system Bio-Rad. Low molecular weight protein standard ranged from 20-97 KD was used to determine the molecular weight of the purified lipase.

\section{Effect of organic solvent on lipase stability}

In order to study the effect of organic solvents on enzyme stability, suitably diluted purified lipase in $50 \mathrm{mM}$ Tris- $\mathrm{HCl}(\mathrm{pH} 9.0)$ was mixed with differen organic solvents to yield a final concentration of $(25 \%, \mathrm{v} / \mathrm{v})$ and then the mixture was incubated on a shaking incubator $(180 \mathrm{rpm})$ at $4{ }^{\circ} \mathrm{C}$ for $48 \mathrm{~h}$. The residua lipase activity was measured using p-NPP method. The used organic solvents were hexane, xylene, toluene, benzene, dichloromethane, diethylether, ethylacetate, isopraponal, acetone, acetonitrile, methanol and dimethyl sulfoxide (DMSO). The initial lipase activity (without containing organic solvents) was considered to be $100 \%$.

\section{Effect of pH on activity and pH stability of PS11 lipase}

The optimum $\mathrm{pH}$ of purified lipase was determined by incubating it with various buffers at a pH range of (4.0-12.0) and lipase activity was determined under standard assay conditions. The $\mathrm{pH}$ stability of the enzyme was characterized by preincubating the purified enzyme with different buffers at $\mathrm{pH}$ range from 4.0 to 12.0 at $4{ }^{\circ} \mathrm{C}$ for $2 \mathrm{~h}$ and assayed for lipase activity. Buffer systems were used at a concentration of $50 \mathrm{mM}$ : acetate- $\mathrm{HCl}$ buffer $(\mathrm{pH} 4.0-5.0)$, sodium hydrogen phosphate- $\mathrm{NaOH}$ buffer ( $\mathrm{pH}$ 6.0-7.0), Tris- $\mathrm{HCl}$ buffer $(\mathrm{pH} 7.0-9.0)$, disodium hydrogen orthophosphate- $\mathrm{NaOH}$ buffer $(\mathrm{pH} 9.0-11.0)$, and glycine- $\mathrm{NaOH}$ buffer (pH 10.0-12.0).

\section{Effect of temperature on activity and temperature stability of PS11 lipase}

The effect of temperature on purified lipase was determined by incubating the reaction mixture at a temperature range of $10^{\circ}-80^{\circ} \mathrm{C}$ under standard assay conditions. The thermostability of the enzyme was determined by incubating the enzyme at different temperatures from $10^{\circ}$ to $80^{\circ} \mathrm{C}$ for $2 \mathrm{~h}$ and lipase activity was determined.

\section{RESULTS AND DISCUSSION}

\section{Measurement of bacterial growth and lipase production}

Time course of cell growth and lipase production by PS11 in production medium are shown in figure 1 . The bacteria exhibited a minimal lag phrase. The exponential phase lasted up to $18 \mathrm{~h}$ and the stationary phase continued till $90 \mathrm{~h}$. A slight decline in biomass was noted after $96 \mathrm{~h}$ probably due to nutrient depletion. The findings are similar with results reported by Abada (2008).

Lipase production was noted from the early stationary phase (24h) but the production attained maximum level $(760 \mathrm{EU} / \mathrm{ml})$ during the late stationary phase ( $72 \mathrm{~h}$ ) of the microorganism suggesting that the extracellular lipase is a secondary metabolite. Furthermore, the enzyme activity gradually decreased after $72 \mathrm{~h}$

Therefore, the optimum incubation periods was maintained throughout the studies.

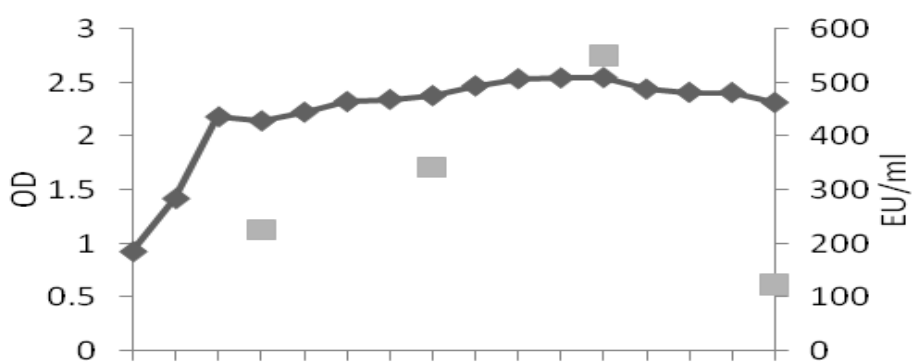

6121824303642485460667278849096

time (h)

\section{Optimization of lipase production media}

Different sources of nitrogen were tested in order to determine their influence on the synthesis of lipase. Peptone showed maximum enzyme activity $(310 \mathrm{EU} / \mathrm{ml})$ as shown in figure 2a. Gunasekaran and Das (2004) has also reported about peptone to augment lipase production

Since each microorganism requires a different carbon source to produce lipase at its maximum level, the influence of different carbon sources was tested. Glucose (367.5 EU/ml) was the best carbon source (figure $2 \mathrm{~b}$ ). In some cases glucose has been found to cause repression of lipase production but the case was opposite for PS11 where glucose acted as an inducer. The present study is in agreement with the findings of (Lakshmi et al. 1999 and Banerjee $\boldsymbol{e t}$ al. 1985) who reported maximum production of lipase in medium containing glucose.

Lipidic sources seem to be essential for obtaining a high lipase yield. Among the various lipidic carbon source tested rice bran oil $(370 \mathrm{EU} / \mathrm{ml})$ best supported lipase production by PS11 (figure 2c.). The high content of fatty acids specifically PUFA in rice bran oil (38\% monounsaturated, $37 \%$ polyunsaturated, and $25 \%$ saturated) might support high level of lipase synthesis.

The production of lipase was observed till $96 \mathrm{~h}$ of incubation and it was highest at $72 \mathrm{~h}(765 \mathrm{EU} / \mathrm{ml})$ during stationary phrase. The results of several other studies have shown the optimum lipase production at varying time period between 12 to 24 h Dharmsthiti et al. (1998) which was in contrast with our results. However it was noted by Kumar $\boldsymbol{e t}$ al. (2005) that a high biomass was obtained at $48 \mathrm{~h}$ of incubation and high lipase activity was found in $72 \mathrm{~h}$ of incubation time in strains of Bacillus cereus. Most Bacillus species required more than 2 days for the maximum lipase activity to occur (Joseph et al. 2006, Wang et al. 2009)

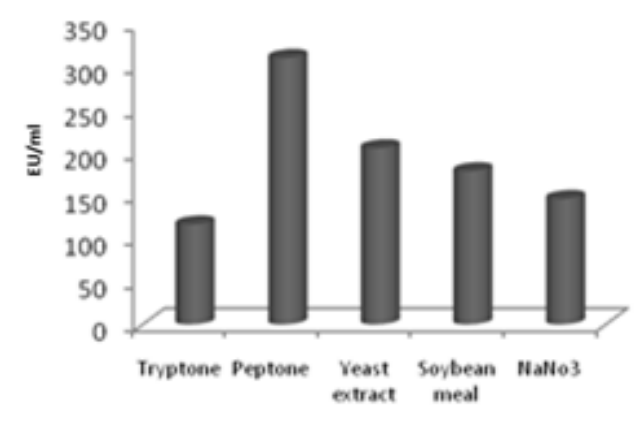

Figure 2(a)

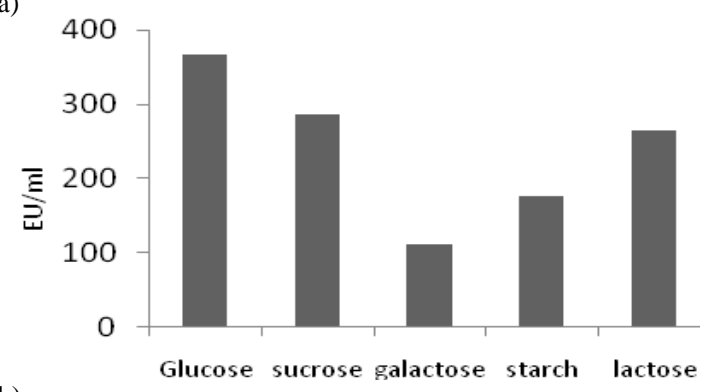

Figure 2(b)

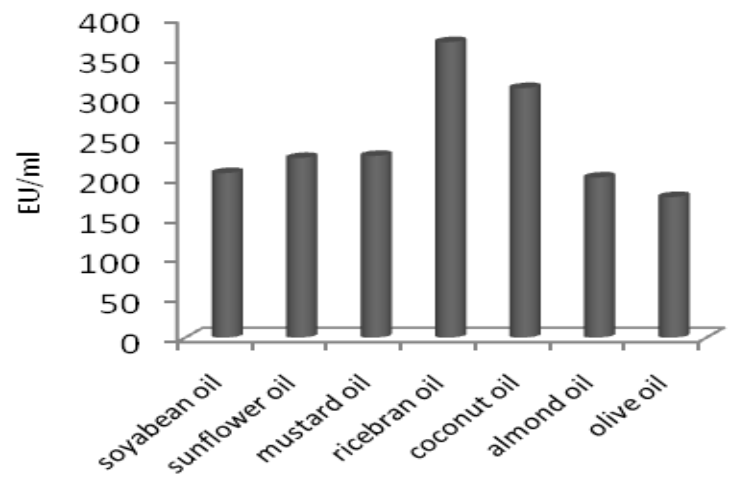

Figure 2(c)

Figure 1 Determination of bacterial growth ( and enzyme ( 


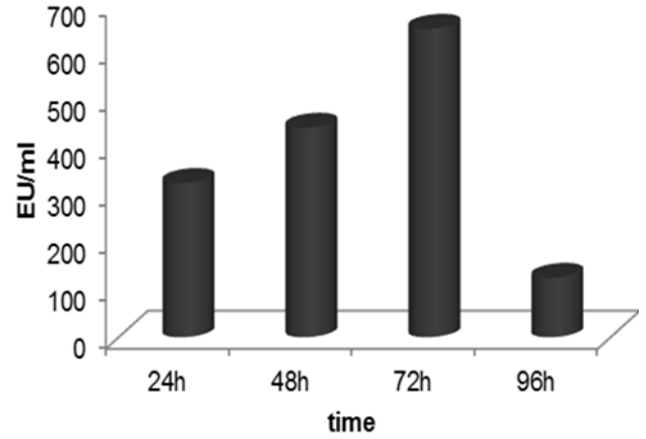

Figure 2(d)

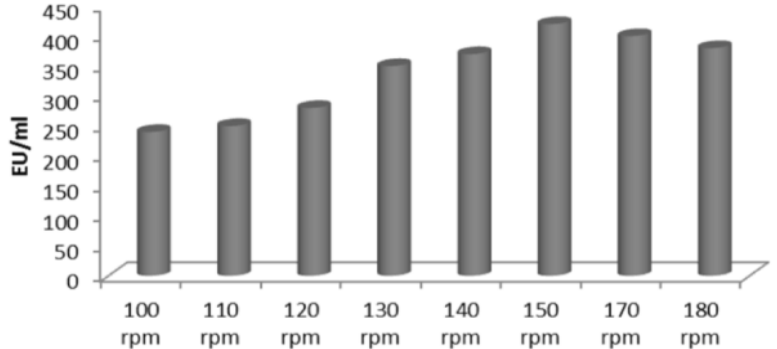

Figure 2(e)
Agitation rates influenced the lipase yield and cell growth. Lipase production increased with increase in agitation speed and reached a maximum at $150 \mathrm{rpm}$ $(420 \mathrm{EU} / \mathrm{ml})$ due to sufficient supply of dissolved oxygen in the media. Further increase in agitation lowered the production of lipase (figure 2e) probably because at a high agitation rate, the structure of enzyme would be altered Microorganisms vary in their oxygen requirements as oxygen acts as a terminal electron acceptor for oxidative reactions to provide energy for cellular activities The variation in the agitation speed influence the extent of mixing in the shake flasks or the bioreactor, oxygen transfer rate, surface area of contact with the media components, dispersability of the carbon source and the nutrient availability.

\section{Purification and molecular weight determination}

Lipase was purified from the extracellular medium by ammonium sulfate precipitation followed by different column chromatography. A large amount of lipase was lost after ammonium sulfate precipitation; less than $50 \%$ of the precipitated lipase was resolubilized. Our three step purification protocol to purify the lipase enzyme from PS11 involving ammonium sulfate precipitation, ion exchange chromatography, and gel filtration chromatography resulted in 8.04 fold purified lipase with $22.6 \%$ recovery rate (Tab 1 ) and the characterizations of the purified enzyme revealed a molecular mass of $27.5 \mathrm{kDa}$ in SDS-PAGE (Figure 3).

Figure 2 Optimization of lipase production. a. nitrogen source, b. carbon source, c. substrate, d. incubation time, e. agitation rate

Table 1 Purification of lipase from PS11 strain

\begin{tabular}{lcccc}
\hline Step & Total EU & Total Protein(mg) & $\begin{array}{c}\text { Specific activity } \\
\text { (EU/mg) }\end{array}$ & $\begin{array}{c}\text { Purification fold } \\
(\%)\end{array}$ \\
\hline Crude & 323.60 & 28.72 & 11.26 & 1 \\
Ammonium sulphate & 152.60 & 2.90 & 52.62 & 4.67 \\
DEAE-sephacel & 83.60 & 1.46 & 56.96 & 5.05 \\
Sephadex G-75 & 73.37 & 0.81 & 90.58 & 25.83 \\
\hline
\end{tabular}

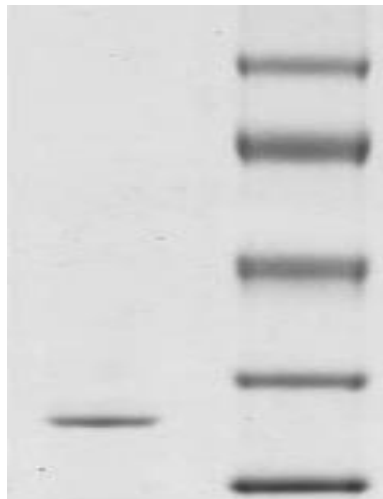

Figure 3 SDS-PAGE of purified lipase from Geobacillus stearothermophilus PS 11.

Lane a: purified lipase from Geobacillus stearothermophilus PS 11. Lane b protein standard : phosphorylase b $(94 \mathrm{kDa})$, bovine serum albumin $(67 \mathrm{kDa})$, ovalbumin $(43 \mathrm{kDa})$, carbonic anhydrase $(30 \mathrm{kDa})$ and soyabean trypsin inhibitor (20.1 kDa).

\section{Organic solvent stability of lipase}

To date, some organic solvent stable lipases have been reported. The toxicity of the organic solvents is usually measured by $\log \mathrm{P}$ value (the partition coefficient of the given solvent in an equimolar mixture of octanol and water). The effect of different organic solvents on purified lipase is shown in Table 2. In this study, organic solvents with various $\log \mathrm{P}$ value ranging from low to high were selected. The lipase was stable and restored almost $90 \%$ of its activity when p-xylene, benzene, toluene, and hexane ( $25 \% \mathrm{v} / \mathrm{v}$ each) were added to the purified enzyme for $2 \mathrm{~h}$ at $\mathrm{C}$ and $10 \mathrm{rpm}$. In presence of methanol and ethanol, the residual activity was $42 \%$ and $46 \%$, respectively.
Table 2 Effect of different organic solvent on lipase stability

\begin{tabular}{lll}
\hline Organic solvents & Log P & $\begin{array}{l}\text { Relative activity }(\%) \text { at concentration } \\
\text { of } 25 \%(\mathrm{v} / \mathrm{v})\end{array}$ \\
\hline Control & - & 100 \\
Methanol & -0.76 & 90 \\
Acetonitrile & -0.33 & 30 \\
Ethanol & -0.24 & 76 \\
Acetic acid & -0.23 & 18 \\
Benzene & 2.0 & 81 \\
Toluene & 2.5 & 92 \\
P-xylene & 3.1 & 91 \\
n-Hexane & 3.1 & 80 \\
Hexane & 3.6 & 86 \\
\hline
\end{tabular}

$25 \%(\mathrm{v} / \mathrm{v})$ of organic solvents were added to the enzyme solution and incubated for $48 \mathrm{~h}$ in a rotary shaker $(180 \mathrm{rpm})$ at $4{ }^{\circ} \mathrm{C}$.

A similar result was shown by the lipase from Staphylococcus saprophyticus M36; the residual activity was $32 \%$ and $36 \%$, respectively, when methanol and ethanol $(25 \% \mathrm{v} / \mathrm{v})$ were added to the enzyme up to for 15 days at $30 \mathrm{C}$ and 160 rpm Fang et al. (2006).

The stability of the PS11 lipase in organic solvents did not follow the $\log P$ trends. The greater is the polarity, the lower the $\log \mathrm{P}$ value and the greater the toxicity of solvent. It is well known that water acts as a lubricant that affords a high conformational fexibility to enzyme molecules. If one follows the trends of $\log P$, the lower the $\log P$ values, the less hydrophobic the solvent, so the enzyme is less stable and there may be change in the conformation of the enzyme molecules. However, different organic solvents showed different tolerance profiles to the PS11 lipase. It is well-known that the effect of organic solvents on enzyme activity differs from lipase to lipase Sugihara et al. (1993). There was no clear correlation between the solubility of an organic solvent in water and stability of lipase in its presence Ogino et al. (2000). 


\section{Effect of pH on activity and pH stability of PS11 lipase}

PS11 was inoculated in the lipase production medium and incubated at a wide range of $\mathrm{pH}$ (4- 12). At $\mathrm{pH} 10$, maximum lipase activity of $417.5 \mathrm{EU} / \mathrm{ml}$ was observed (Figure 4.).The enzyme activity gradually increased from $\mathrm{pH} 5$ to its maximum at $\mathrm{pH} 10$.

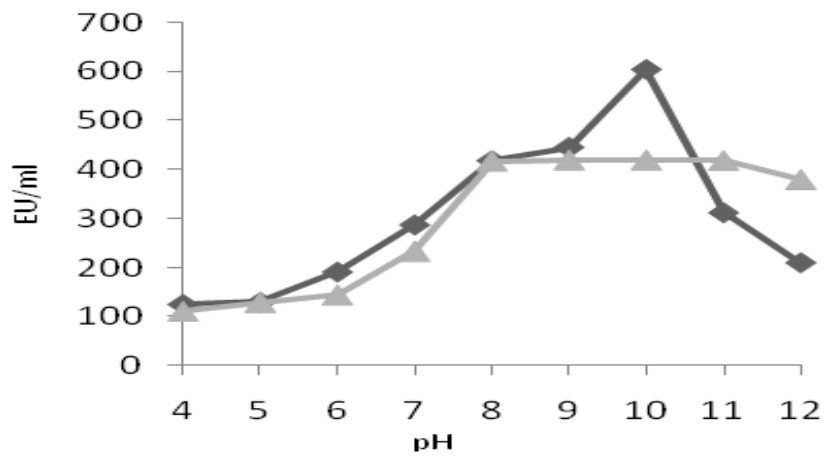

Figure 4 Determination of optimum pH $\diamond$ and pH stability $(\triangle)$ of PS11 lipase

The $\mathrm{pH}$ of the production medium plays a critical role for the optima physiological performances of the bacterial cell and the transport of various nutrient components across the cell membrane aiming at maximizing the enzyme production. Moon and Parulekar (1991) reported that the $\mathrm{pH}$ of culture has been shown to strongly affect many enzymatic processes and transportation of various components across the cell membrane. The effect of $\mathrm{pH}$ on the stability of lipase was tested by incubating the enzymes over a range of $\mathrm{pH}$ values. The enzyme also exhibited stability in high alkaline $\mathrm{pH}$ which is an important industrial attribute.

\section{Effect of temperature on activity and temperature stability of PS11 lipase}

Temperature is a critical parameter which needs to be controlled and this usually varies from organism to another. The optimum temperature for the lipase production was $50^{\circ} \mathrm{C}$, although at $40^{\circ} \mathrm{C}$ the enzyme activity was good. The lipase activity gradually decreased and reached a minimum at $70^{\circ} \mathrm{C}$ (Figure 5).

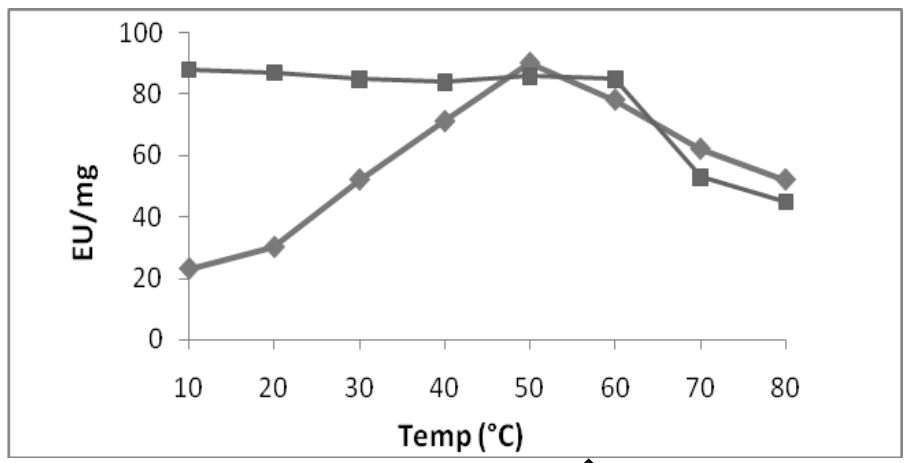

Figure 5 Determination of optimum temperature $(\diamond)$ and temperature stability (प) of PS11 lipase

The enzyme stability was tested by exposing the enzyme to different temperatures for $2 \mathrm{~h}$. PS 11 showed highest activity at $50^{\circ} \mathrm{C}$ and its activity remained stable from $10^{\circ} \mathrm{C}$ to $60^{\circ} \mathrm{C}$. The activity further declined as the temperature increased to $70^{\circ} \mathrm{C}$ showing that the enzyme was not stable at high temperatures. The studies by Frankena et al. (1986) showed that there was a link between enzyme synthesis and energy metabolism in bacteria, and this was controlled by the temperature and oxygen uptake. As for the extra-cellular enzymes, temperature was found to influence their secretion, possibly by changing the physical properties of the cell membrane. It is a well-known fact that the protein conformation is changed or degraded at higher temperatures, and hence a decrease in the lipase activity was noted at higher temperatures.

\section{CONCLUSION}

The major challenge of biodiesel catalyzed by lipase is that its activity significantly reduces in presence of organic solvents, especially methanol and ethanol. Therefore, in this study the solvent tolerant lipase of $27.5 \mathrm{kDa}$ was purified from Geobacillus stearothermophilus PS11 that could be very useful for biodiesel production as it is stable in presence of methanol and ethanol.

\section{REFERENCES}

ABADA, E.A.E. 2008. Production and characterization of a mesophilic lipase isolated from Bacillus steareothermophilus. AB-1. Pakistan Journal of Biological Science, 11, 1100-1106. http://dx.doi.org/10.3923/pjbs.2008.1100.1106

BANERJEE, M., SENGPUTA, I., MAJUMDAR, S.K. 1985. Lipase Production by Hansenula anomala var. Schnegii. Journal of Food Science and Technology, 22, 137-139.

BARNWAL, B. K., SHARMA, M. P. 2005. Prospects of biodiesel production from vegetable oils in India. Renewable Sustainable Energy Reviews, 9, 363 378. http://dx.doi.org/10.1016/i.rser.2004.05.007

DHARMSTHITI, S., PRATUANGDEJKUL, J., THEERAGOOL, G., LUCHAI, S. 1998. Lipase activity and gene cloning of Acinetobacter calcoaceticus LP009. Journal of General and Applied Microbiology, 44, 139-145. http://dx.doi.org/10.2323/jgam.44.139

FANG, Y., ZHAOXIN, L., FENGXIA, L., XIAOMEI, B., SHU, L. ZHONGYANG, D., WEIFENG, X. 2006. A Newly Isolated Organic Solvent Tolerant Staphylococcus saprophyticus M36 Produced Organic Solvent-Stable Lipase. Current Microbiology, 53, 510-515. http://dx.doi.org/10.1007/s00284006-0260-X

FRANKENA, J., KONINGSTEIN, G.M., VAN, VERSEVELD, H.W., STOUTHAMER, A.H. 1986. A continuous culture study of the bioenergetic aspects of growth and production of exocellular protease in Bacillus licheniformis. $\quad$ Applied $\quad$ Microbiology, 24, 106-112. http://dx.doi.org/10.1007/bf00253604

GUNASEKARAN, V., DAS, D. 2004. Lipase fermentation: progress and prospects. Indian Journal of Biotechnology, 4, 437-445.

HUN, C.J., ZALIHA, R. N., RAHMAN, A., SALLEH, A.B., BASRI, M. 2003. A newly isolated organic solvent tolerant Bacillus sphaericus $205 \mathrm{y}$ producing organic solvent-stable lipase. Biochemical Engineering Journal, 15, 147-151. http://dx.doi.org/10.1016/s1369-703x(02)00185-7

JOSEPH, B., RAMTEKE, P.W., KUMAR, P.A. 2006. Studies on the enhanced production of extracellular lipase by Staphylococcus epidermidis. Journal of General and Applied Microbiology, 52 (6), 315-320. http://dx.doi.org/10.2323/jgam.52.315

KAIEDA, M., SAMUKA,WAT., KONDO, A., FUKUDA, H. 2001. Effect of methanol and water contents on production of biodiesel fuel from plant oil catalyzed by various lipases in a solvent-free system. Journal of BioScience and Bioengineering, 91, 12-15. http://dx.doi.org/10.1016/s1389-1723(01)80103-1

KUMAR, S., KIKON, K., UPADHYAY, A., KANWAR, S.S., GUPTA, R. 2005 Production, purification, and characterization of lipase from thermophilic and alkaliphilic Bacillus coagulans BTS-3. Protein Expression and Purification, 41, 38-44. http://dx.doi.org/10.1016/i.pep.2004.12.010

LAKSHMI, B.S., KANGUEANE, P., ABRAHAM, B., PENNATHUR, G. 1999 Effect of Vegetable Oils in the Secretion of Lipase from Candida rugosa (DSM 2031). Letters in Applied Microbiology, 29, 66-70 http://dx.doi.org/10.1046/j.1365-2672.1999.00578.x

LOWRY, O., ROSBROUGH, N, FARRA., RANDALL, R. 1951. Protein measurement with the folin phenol reagent. Journal of Biological Chemistry, $193,265-275$

MARCHETTI, J.M., MIGUEL, V.U., ERRAZU, F. 2005. Possible methods for biodiesel production. Renewable Sustainable Energy Reviews, 11(6), 1300-1311. http://dx.doi.org/10.1016/j.rser.2005.08.006

MOON, S.H., PARULEKAR, S.J. 1991. A parametric study of protease production in batch and fed-batch culture of Bacillus firmus. Biotechnology and Bioengineering, 37(5), 467-483. http://dx.doi.org/10.1002/bit.260370509

OGINO, H., NAKAGAWA, S., SHINYA, K., MUTO, T., FUJIMURA, N., YASUDO, M., ISHIKAWA, H. 2000. Purification and characterization of organic solvent tolerant lipase from organic solvent tolerant Pseudomonas aeruginosa LST-03. Journal of BioScience and Bioengineering, 89, 451-457. http://dx.doi.org/10.1016/s1389-1723(00)89095-7

SARKAR, P., GHOSH, S. 2012. Bioremediation potential of a newly isolate solvent tolerant strain Bacillus thermophilus PS11. Journal of BioScience and Biotechnology, 1(2), 141-147.

SHIMADA, Y., SUGIHARA, A., UESHIMA, M., TSUNASAWA, S., TOMINAGA, Y. 1993. Purification and characterization of a novel solventtolerant lipase from Fusarium heterosporum. Journal of Fermentation and Bioengineering, $\quad 75(5), \quad 349-352 . \quad$ http://dx.doi.org/10.1016/0922 338x(93)90132-r

VAN, G.J. 2005. Biodiesel processing and production. Fuel Processing Technology, 86, 1097-1107. http://dx.doi.org/10.1016/i.fuproc.2004.11.005

WANG, X., YU, X., XU, Y. 2009. Homologous expression, purification and characterization of a novel high-alkaline and thermal stable lipase from Burkholderia cepacia ATCC 25416. Enzyme Microbial Technology, 45, 94-102. http://dx.doi.org/10.1016/j.enzmictec.2009.05.004 